\title{
Kafa İçi Basınç Artışı Sendromundan Beyin Ölümü ve Organ Donasyonuna Giden Bir Adölesan Olgu Sunumu
}

\author{
Organ Donation Following Brain Death Due to Increased Intracranial \\ Pressure: An Adolescent Case Report \\ Emine Gülşah TORUN ${ }^{1}$, Mutlu UYSAL YAZICl ${ }^{2}$, Ebru AZAPAĞASI ${ }^{2}$, Fatih Mehmet Akif ÖZDEMIR ${ }^{3}$, \\ Nesrin CEYLAN ${ }^{3}$
}

\begin{abstract}
'Sağlık Bilimleri Üniversitesi Dr. Sami Ulus Kadın Doğum, Çocuk Sağlığı, Hastalıkları Eğitim ve Araştırma Hastanesi Çocuk Sağlığı ve Hastalıkları Kliniği, Ankara, Türkiye

2Sağlık Bilimleri Üniversitesi Dr. Sami Ulus Kadın Doğum, Çocuk Sağlığı, Hastalıkları Eğitim ve Araştırma Hastanesi, Pediatri Yoğun Bakım Kliniği Ankara, Türkiye

${ }^{3}$ Sağlık Bilimleri Üniversitesi Dr. Sami Ulus Kadın Doğum, Çocuk Sağlığı, Hastalıkları Eğitim ve Araştırma Hastanesi, Çocuk Nöroloji Kliniği, Ankara, Türkiye
\end{abstract}

\begin{abstract}
ÖZ
Beyin, beyin sapı ve serebellum fonksiyonlarının geri dönüşümsüz kaybı beyin ölümü olarak tanımlanmaktadır. Geri dönüşümsüz beyin hasarı saptanan, tıbben beyin dışındaki organları sağlıklı olan donörler uygun organ donörü olabilirler. Son yillarda organ naklindeki büyük gelișmelere rağmen, organ naklinin en önemli sorunu organ bağıșındaki yetersizliktir. Bu nedenle organ donörü sağlanması açısından çocuk yoğun bakım ünitelerinde beyin ölümü tanısı koymak oldukça önemlidir. Burada 17 yaşında kafa içi basınç artışı sendromuna (KIBAS) bağlı beyin herniasyonu olan ve sonrasında beyin ölümü tanısı alan, böbrek, kornea ve akciğer nakli için donör olan bir olgu sunulmuştur.
\end{abstract}

Anahtar Sözcükler: Adölesan, Akciğer Nakli, Beyin Ölümü, Kafa içi Basınç Artış Sendromu, Doku ve Organ Bağışı

\begin{abstract}
Brain death is defined as the irreversible loss of all functions of the brain, the brainstem and cerebellum. Donors with irreversible brain damage and medically healthy organs other than the brain may be suitable organ donors. Despite the great progress on organ transplantation in recent years, the most important problem of organ transplantation is the insufficiency in organ donation. Therefore, it is very important to diagnose brain death in pediatric intensive care units to provide organ donors. Herein, we report a 17-year-old patient who had brain herniation due to increased intracranial pressure and was subsequently diagnosed with brain death. The patient's organs including the lungs, both kidneys and both corneas were retrieved for donation.
\end{abstract}

Key Words: Adolescent, Lung Transplantation, Brain Death, Intracranial Hypertension Increase Syndrome, Tissue and Organ Procurement

\section{GiRiş}

Kafa içi basınç artışı sendromu (KiBAS), intrakranial yer kaplayan bir kitlenin (tümör, hematom, abse gibi) gelişmesi; ekstra veya intrasellüler SIVı miktarının artması (beyin ödemi); beyin kan akımının artması, beyin omurilik sıvı miktarının artması nedeniyle olușabilir (1). Hayatı tehdit eden, hızı değerlendirme ve tedavi gerektiren acil bir durumdur. Çocuklarda KiBAS'ın erken tanı ve doğru yönetimi ile kalıcı beyin hasarı gelişimi engellenebilir.

Beyin, beyin sapı ve serebellum fonksiyonlarının ve asendan retiküler aktive edici sistemin geri dönüşümsüz kaybı beyin ölümü olarak tanımlanmaktadır (2). Son yıllarda organ naklindeki büyük gelişmelere rağmen, organ naklinin en önemli sorunu organ bağıșındaki yetersizliklerdir. Ülkemizde beyin ölümü
(1)
Geliş tarihi / Received : 25.02.2021 Kabul tarihi / Accepted : 20.04.2021 Elektronik yayın tarihi : :14.09.2021 Online published

DOI: 10.12956/tchd.885694 
sonrası organ bağışı oranları düşüktür $(3,4)$. Organ donörü sağlanması için çocuk yoğun bakım ünitelerinde beyin ölümü tanısı koymak ve iyi bir donör bakımı yapmak oldukça önemlidir.

Bu yazıda KIBAS olan bir olguda beyin ölümü, potansiyel donör bakımı ve organ donasyonu tartışımıştır.

\section{OLGU}

Daha öncesinden şikâyeti olmayan 17 yaşında erkek hasta aniden başlayan şiddetli baş ağrısı, bulantı ve kusma nedeniyle yaşadığı ildeki sağlık merkezine başvurmuş. Hastaya metoklopramid ve diklofenak sodyum intramuskuler tedavileri uygulanmış ve eve gönderilmiş. Hastanın eve gittikten 2 saat sonra jenaralize tonik klonik nöbetleri başlamış. 112 aracilığıyla son başvurduğu hastaneye getirilen hastanın glaskow koma skalası (GKS) 9 olarak değerlendirilmiş. Tetkiklerinde c-reaktif protein (CRP) değerinde 4 kat artış gözlenmiş ve ateşi $39^{\circ} \mathrm{C}$ ölçülmüş. Tek doz seftriakson yapılmıs. Hastanın çekilen Kranial BT'si normal olarak değerlendirilmiş. Nöbetleri midazolam, fenitoin ve levatiresetam ile kontrol altına alınamayan hasta ensefalit, status epileptikus (SE) tanıları ile yoğun bakım ünitesi olan başka bir hastaneye sevk edilmiş. Transport sırasında ambulans içinde saturasyonu düşen ve bradikardisi olan hastaya 3 dakika kardiyopulmoner resüsitasyon uygulanmış ve hasta entübe edilmiş. Hastanın ikinci kabul edildiği hastanede genel durumu kötü, GKS 3 ve pupilleri fix dilateymiş. Hastaya sefriakson, vankomisin, asiklovir, klaritromisin ve oseltamivir tedavisi başlanmış. Kranial BT normal olarak değerlendirilmiş. Hasta 112 aracılığılla ileri tetkik ve tedavi amacıyla hastanemiz çocuk yoğun bakım ünitesine (ÇYBÜ) kabul edildi.

Hastanın öyküsünden 1 yı önce araç dışı trafik kazası geçirdiği, trafik kazası sonrasında kafa tabanı kırı̆ı ve pnömosefalisi olduğu ve nöbet geçirdiği, bu nedenle fenitoin başlandığı öğrenildi. Ancak hasta kendi isteği ile ilaçlarını 2 yıldır kullanmıyormuş.

Geliş fizik muayenesinde; genel durumu kötü, bilinç kapalı, GKS 3, tansiyon 76/43 mmHg, kalp tepe atımı 85/dk, oksijen saturasyonu \%90'dı. Bilateral ışık refleksi ve beyin sapı refleksleri alınamadı, pupilleri sabit dilateydi, spontan solunumu yoktu. Hastanın ense sertliği vardı. Diğer sistem muayeneleri normaldi. Hastanın başvurduğu merkezde sevk edilmeden önce GKS'sı 9 ve kranial BT'sinin normal olduğu öğrenilmişti. Fakat hastanın merkezimize başvurusunda GKS'sı 3'dü ve beyin ölümü bulguları (derin koma durumu, beyin sapı areflexisi) mevcuttu.

Hastanın tetkiklerinde: hemoglobin: $15.8 \mathrm{gr} / \mathrm{dl}$, beyaz küre:

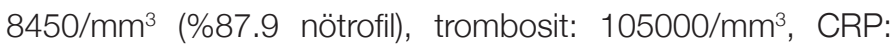
234,5 mg/L, kreatinin: $1.01 \mathrm{mg} / \mathrm{dL}$, kreatin kinaz: $1656 \mathrm{IU} / \mathrm{L}$, troponin l: $2.55 \mathrm{ng} / \mathrm{mL}$, kan gazl; $\mathrm{pH}: 7.29, \mathrm{pCO} 2: 31 \mathrm{mmHg}$, pO2: 70 mmHg, HCO-3: 15 mmol/tt, BE: -10 mmol/tt, laktat: 20 $\mathrm{mg} / \mathrm{dL}$ olarak saptandı. Elektrolit dengesizliği yoktu ve karaciğer fonksiyon testleri normaldi. Olası intoksikasyon açısından serum ve idrardan ilaç düzeyleri gönderildi.

Geldiği hastanede ensefalit düşünülerek başlanılan seftriakson, oseltamivir, klaritromisin ve vankomisin tedavilerine devam edildi. Basınç kontrollü SIMV modda izleme alındı. Hipotansif olan hastaya adrenalin ve dopamin infuzyonu başlandı ve dozları titre edildi. Levatiresetam $(20 \mathrm{mg} / \mathrm{kg})$ bir $\mathrm{kez}$ daha yüklenerek idame tedaviye geçildi. Çekilen EEG'sinde her iki hemisferde de izoelektrik serebral aktivitenin izlendiği epileptik aktivite izlenmediği görüldü.

İkinci hastanede çekilen Kraniyal BT hastanemiz radyoloji bölümü tarafindan tekrar değerlendirildi. Yaygın beyin ödemi ve tonsiller herniasyon görüldü (Resim 1). Lumbar ponksiyon kontraendike olduğu için yapılmadı. Antiödem tedavi hipertonik (\%3 NaCl) salin verildi. İnotop adrenalin $1 \mathrm{mcq} / \mathrm{kg} / \mathrm{dk}$, noradrenalin 1.5 $\mathrm{mcq} / \mathrm{kg} / \mathrm{dk}$ ve dopamin $20 \mathrm{mcq} / \mathrm{kg} / \mathrm{dk}$ dozlarına kadar çıkıldı. Hastanın serum ve idrarında ilaç düzeyi saptanmadı. Zehirlenme düşünülmedi. Hastadan etiyolojiye yönelik gönderilen kan kültüründe ve idrar kültüründe üreme olmadı. Gönderilen geniş kapsamlı viral seroloji negatif saptandı.

Yatışının ilk günü ve ikinci günü, 24 saat arayla yapılan iki nörolojik muayenesinin beyin ölümü ile uyumlu olması üzerine hastaya apne testi yapıldı ve test pozitif saptandı. Kraniyal BT

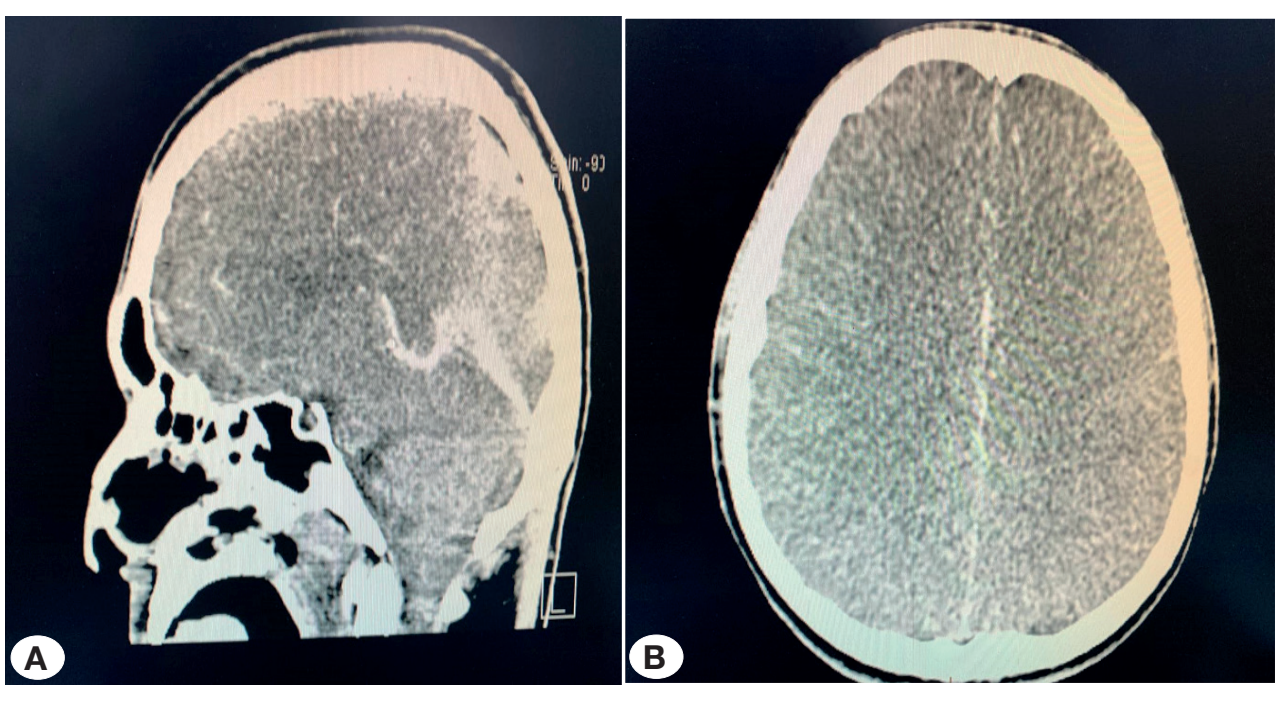

Resim 1: Vakanın kranial BT'sinde; A'da sagittal kesitte serebellar tonsillerin foramen magnumdan herniye olduğu ve B'de transverse kesitte beyin ödemi görülmektedir. 
Anjiografi çekilerek beyin ölümü tanısı doğrulandı. Hastanın almakta olduğu asiklovir tedavisi nefrotoksik olduğu için kesildi. Hastanın kreatinin değerlerinde yükseklik olduğu için sürekli renal replasman tedavisi (SRTT) başlandı.

Beyin ölümü tanısı aileye deklare edildikten sonra organ nakil koordinasyonu tarafindan donosyon teklifinde bulunuldu. Aile organ donörü olmayı kabul etti. Hastanın her iki böbreği, korneası ve akciğerleri transplant edildi.

\section{TARTIŞMA}

Burada 17 yașında KIBAS'a bağı beyin herniasyonu olan ve sonrasında beyin ölümüme giden bir olgu tartışılmıştır. Olgu beyin ölümü tanısı aldıktan sonra organ donörü olmuştur.

Çocuklarda KIBAS'a en çok kafa travması, intrakraniyal enfeksiyonlar veya kafa içi kitleler sebep olmaktadır (1). KiBAS, altta yatan nedeni tersine çevirmeye yönelik hızı tanıma ve tedavi gerektirir. KIBAS olan hastaların hava yolu yönetimi acildir. KIBAS'tan şüphelenilen hastalarda hızı ardışık entübasyonun (HAE) hava yolunun güvenliğini sağlamak için tercih edilmelidir. Bu öneri, HAE'nin yüksek başarı oranına ve düşük komplikasyon insidansına dayanmaktadır $(5,6)$. GSK'sı 9 iken ambulansa alınan hastanın sevk olduğu hastanedeki GSK'nın 3 olması, hastada KIBAS'a bağı herniasyon geliştiğini düşündürmektedir.

Beyinölümü, beyinfonksiyonlarının geridönüşümsüzkaybılarak tanımlanır. Ülkemizde, beyin ölümü tanısı biri nörolog veya beyin cerrahi, biri de anesteziyoloji ve reanimasyon veya yoğun bakım uzmanından oluşan iki hekim tarafından oy birliği ile konulur. Beyin ölümü klinik tanısının 3 temel bulgusu derin koma durumu, beyin sapı arefleksisi ve pozitif apne testidir. Beyin ölümü temel bulgularının saptandıktan sonra geri dönüşümsüzlük kriterinin sağlanması için beyin ölümü bulgularının belirlenen sürede değişmediği gösterilmelidir (2). Beyin ölümü klinik tanısı serebral kan dolaşımı veya beyin elektriksel aktivitesi hakkında bilgi veren testler ile desteklenmelidir. Elektroensefalografi, duyusal uyarımış potansiyeller, transkranial doppler ultrasonografi, radyonüklid serebral sintigrafi (SPECT), BT anjiyografi ve kateter serebral anjiyografiyi destekleyici testlerdir (2).

Ülkemiz beyin ölümü teșhisi konan donörlerden organ nakli yapılmasına izin veren ilk ülkelerden olmasına (7) ve gerekli olanaklara sahip olmasına rağmen, beyin ölüm bildirimlerinin sayısı ve organ nakli oranı düşüktür $(4,8)$. Ülkemizde 2019 verilerine göre; 28 bin 272 hasta nakil için sıradadır (8). Türkiye'de 1975'ten beri böbrek nakli yapılmaktadır ve ülkemizde en çok nakil yapılan organ da böbrektir (9). Akciğer nakli, tüm organ nakilleri içinde en komplike organ naklidir. Ülkemizde. ise ilk başarılı akciğer nakli 2009 ylında yapıımıştır (10). Ülkemizde organ nakli bekleyen hasta sayısı her yl yaklaşık \%20 civarında artmaktadır ve organ bekleyen hastaların \%10 undan fazlasının bu süreçte hayatını kaybetmektedir. Organ nakli bekleyen hasta sayısı her yıl yaklaşık yüzde 20 civarında artmaktadır ve hastaların yüzde 10'undan fazlasının organ beklerken hayatını kaybetmektedir. 2019 verilerine göre; 2 bin 309 beyin ölümü bildiriminden 256'sı 0-19 yaş arasındadır ve bu hastalardan yalnızca 52 hasta organ donörü olmuştur (8). Bu nedenle, beyin ölümü erken tanısı ve donör organların bakımı son derece önemlidir.

Hastamızın gelişindeki nörolojik muayenesinde beyin ölümü kliniği hızlıca tanındı. Yapılan apne testi ve çekilen BT anjiyografisi beyin ölümü tanısı doğrulandı. Hastamıza beyin ölümü tanısı konulduktan sonra organların işlevlerinin korunması hedeflendi. Transplantasyonu yapılacak organlar travma, hipoksi, şok, anemi, kan ürünlerine maruziyet ve enfeksiyon sebebiyle hasar görebilir $(11,12)$. Potansiyel organ bakımının amacı yeterli organ perfüzyonu ve yeterli doku oksijenasyonunu sağlamaktır. Bunun için vücut sıcaklığının korunması $\left(35-37^{\circ} \mathrm{C}\right)$, kalp debisinin optimal düzeyde tutulması, yeterli ventilasyon sağlanması (oksijen saturasyon>\%95, pH: 7.35-7.45) idrar çıkısının 1-2 ml/kg/sa tutulması gibi hedefler belirlenmiştir $(12,13)$. Hastamıda organ bakımı amacıyla; elektrolit dengesini sağlandı, kan basıncının stabilizasyonu için aşamalı çoklu inotrop tedavisi başlandı, akciğer koruyucu mekanik ventilatör stratejisi uygulandı. Yapılan çalışmalar beyin ölümünde akut renal hasarın erken döneminde yapılan renal replasman tedavilerinin böbrek nakil intimalini arttırdığını göstermiştir (14,15). Biz de hastamıza böbrek fonksiyon testlerinde bozukluk ve idrar çıkısında azalma olması nedeniyle SRRT tedavisi uyguladık. Hastanın ünitemizde hızla konulan beyin ölümü tanısı ve organların korunmasına yönelik uygun yoğun bakım hizmeti sayesinde nadir bir transplantasyon işlemi olan akciğer nakline gidişi sağlandı. Aynı zamanda her iki böbreği de iki ayrı hastada kullanılabildi.

Bu vaka, beyin ölümü tanısının hızlı konulması ve organların uygun şekilde korunmasının önemini vurgulamak amacı ile sunulmuştur.

\section{KAYNAKLAR}

1. Rangel-Castilla L, Gopinath S, Robertson CS. Management of intracranial hypertension [published correction appears in Neurol Clin 2008;26: xvii.

2. Türk Nöroloji Derneği Beyin Ölümü Tanı Klavuzu 2014; 20: 101-4.

3. Şantaş G, Şantaş F. Türkiye'de organ bağışının mevcut durumu ve organ bağışında stratejik iletişimin önemi. Süleyman Demirel Üniversitesi Sağlık Bilimleri Dergisi 2018;9:163-8.

4. Gündüz RC, Sahin S, Uysal-Yazici M, Ayar G, Yakut HI, ve ark. Brain death and organ donation of children. The Turkish journal of pediatrics 2014;56:597-603.

5. Sagarin MJ, Chiang V, Sales JC, Barton ED, Wolfe RE, Vissers RMW, ve ark. Rapid sequence intubation for pediatric emergency airway management. Pediatr Emerg Care 2002;18:417-23.

6. Gerardi MJ, Sacchetti AD, Cantor RM, Santamaria JP, Gauche M, Lucid W, ve ark. Rapid-sequence intubation of the pediatric patient. Pediatric Emergency Medicine Committee of the American College of Emergency Physicians. Ann Emerge Med 1996;28:55-74. 
7. Yasa no. 223829 Mayıs 1979 Organ ve Doku Alınması, Saklanması, Așılanması ve Nakli Hakkında Kanun. TC Resmi Gazete 3 June 1979; 16655: 1-4.

8. Doku, Organ Nakli ve Diyaliz Hizmetleri Dairesi Başkanlığı, Türkiye Transplantasyon, Diyaliz İzlem Sistemleri, erişim 19.04.2020 https://organkds.saglik.gov.tr/dss/PUBLIC/Public Default2.aspx

9. Haberal M. Historical evolution of kidney and liver transplantation in Turkey. Transplant Proc1995;27:2771-4.

10. Türk Toraks Derneği, Ülkemizde Akciğer Nakli, erişim 19.04.2020, https://www.toraks.org.tr/halk/News.aspx? detail=3810

11. https://www.aa.com.tr/tr/saglik/turkiye-genelinde-gecen-yil-9-bin477-organ-ve-doku-nakli-yapildi/1690942 erişim tarihi 18 ocak 2021.

12. Bayrakcı B, Çocuk Yoğun Bakım Ünitesinde Organ Donörünün Tıbbi Bakımı. Yoğun Bakım Dergisi 2004;4:186-9.
13. Kotloff RM, Blosser S, Fulda GJ, Malinoski D, Ahya, VN, ve ark. Management of the potential organ donor in the ICU: Society of Critical Care Medicine/American College of Chest Physicians/ Association of Organ Procurement Organizations Consensus Statement. Crit Care Med 2015; 43: 1291-325.

14. Park J, Yang NR, Lee YJ, Hong KS. A Single-Center Experience with an Intensivist-Led Brain-Dead Donor Management Program. Ann Transplant 2018;23:828-35

15. Friedman AL, Marquez E, Lewis JA. Organ Donation is an Indication for Renal Replacement Therapy (RRT). Am J Transplant. 2019; 19 (suppl 3). https://atcmeetingabstracts.com/abstract/ organ-donation-is-an-indication-for-renal-replacement-therapyrrt/. Accessed June 12, 2020. 